\title{
KEMAMPUAN MENULIS PARAGRAF DESKRIPSI DENGAN MENGGUNAKAN MEDIA GAMBAR FOTOGRAFI KELAS VII SMP SWASTA PARULIAN 1 MEDAN
}

\author{
Rumondang AgustinaTampubolon ${ }^{1}$ \\ Mahasiswa Bahasa dan Sastra Indonesia UMN Al Washliyah ${ }^{1}$ \\ tampubolonagustina723@gmail.com \\ Rosmawati Harahap ${ }^{2}$ \\ Dosen Bahasa dan Sastra Indonesia UMN Al Washliyah ${ }^{2}$ \\ dahlanrahmawati59@gmail.com
}

\begin{abstract}
Abstrak
Tujuan penelitian ini adalah ingin mendeskripsikan kemampuan menulis paragraf deskripsi oleh siswa kelas VII SMP Swasta Parulian 1 Medan Tahun Pembelajaran 2017-2018 tanpa menggunakan media gambar fotografi; dan ingin mendeskripsikan kemampuan menulis paragraf deskripsi oleh siswa kelas VII SMP Swasta Parulian 1 Tahun Pembelajaran 2017-2018 dengan menggunakan media gambar fotografi. Metode penelitian ini menggunakan desain penelitian kuantitatif statistik. Populasi penelitian ini tiga kelas siswa kelas VII SMP Swasta Parulian 1 Medan Tahun Pembelajaran 2017-2018; sampel sebagian merupakan sampel dari totalitas siswa tiga kelas VII SM P Swasta Parulian 1 Medan. Instrumennya adalah observasi, tes awal, tes akhir. Teknik pengumpulan datanya dilakukan dengan mengobservasi dan mentesnya. Pengelolahan datanya dengan pemberian skor sesuai rumus statistik deskriptif berdasarkan hasil tes akhir. Hasil penelitian ini bersifat kuantitatif yakni 9 orang dalam skala nilai 65-73 dengan frekuensi $27,27 \%$ bernilai dalam kategori Cukup; dan ada 10 orang berskala nilai 74-84 dalam frekuensinya adalah 33,3\% maka nilainya berkategori Baik; dan ada 14 orang berskala skor 85100 sama dengan 42\% yang berkategori nilai Sangat-Baik. Berdasarkan rumus rerata dan standar deviasi (SD) maka nilai akhir siswa kelas VII SMP Swasta Parulian 1 Medan Tahun Pembelajaran 2017-2018 berkualifikasi >60\%; makanya para siswa tersebut dikatakan mampu menulis paragraf deskripsi karena nilai rata-ratanya adalah 81,3 berkategori nilai baik. Dengan demikian disimpulkan bahwa kemampuan menulis paragraf deskripsi menggunakan media fotografi oleh siswa kelas 7 VII SMP Swasta Parulian 1 Medan tahun pelajaran 2017-2018 umumnya termasuk kategori bernilai baik.
\end{abstract}

Kata kunci: menulis, paragraf, deskripsi, media, gambar fotografi.

\begin{abstract}
The purpose of this study is to describe the ability to write paragraphs descriptions in level 7 SMP Swasta Parulian 1 Medan in 2017-2018 Learning Year without using photographic image media; and want to describe the ability to write paragraph descriptions by level 7 SMP Swasta Parulian 1 Medan in 2017-2018 Learning Year using photographic image media. This research method uses quantitative statistical research design. The study population was three classes of class VII SMP Swasta Parulian 1 Medan in Learning Year 2017-2018; while the sample of the study is a sample of a part of level 7 SMP Swasta Parulian 1 Medan. The instruments are observation, pretest, and post-testing the ability to write descriptive paragraphs. The data collection technique is done by observing and testing. Management of the data by giving a score according to the descriptive statistical formula based on the results of the post test. The results of quantitative research, namely 9 people on a scale of $65-73$ at a frequency of $27.27 \%$ are the values of enough categories; and there are 10 people with a score of 74-84 in the frequency is $33.3 \%$, the value is in the Good category; and there are 14 people on a scale of 85-100 equal to $42 \%$ categorized as Very Good. Based on the mean formula (M) and standard deviation (SD), the final grade of grade VII students of SMP Swasta Parulian 1 Medan in 2017-2018 Learning Year was
\end{abstract}


qualified $>60 \%$ so it is said to be able to write paragraph descriptions because the average value is 81, 3 in good value category. Thus it was concluded that the ability to write paragraphs of description using photographic media by level 7 VII students of SMP Swasta Parulian 1 Medan in 2017-2018 Learning Year was generally good value category.

Keywords: writing, paragraph, descriptions, media, photographic images.

\section{PENDAHULUAN}

\subsection{Latar Belakang Masalah}

Tercatat dalam skripsi yang dilakukan peneliti Rumondang Agustina Tampubolon bahwa hasil observasi awal di SMP Swasta Parulian 1 Medan mengobservasi siswa kelas VII SMP Swasta Parulian 1 Medan Tahun Pembelajaran 2017-2018 tanpa menggunakan media gambar fotografi; dan ingin menggambarkan kemampuan menulis paragraf deskripsi oleh siswa kelas VII SMP Swasta Parulian 1 Tahun Pembelajaran 2017-2018 dengan menggunakan media gambar fotografi. Beberapa masalah pada pembelajaran menulis di antaranya adalah (1) kemampuan siswa dalam menulis paragraf deskripsi masih kurang; (2) motivasi dan minat siswa dalam pembelajaran menulis paragraf deskripsi masih kurang. Dari hasil observasi awal tersebut maka diperlukan pengujian kemampuan menulis siswa di SMP Swasta Parulian 1 Medan Tahun Pembelajaran 2017-2018. Hasil pengujiannya telah mendapatkan hasil berdasarkan indikator prinsip evaluasi pendidikan (Sudjana, 2001), prinsip penelitian deskriptif kuantitatif (Margono, 2010; dan Sugiyono, 2017). Rumusan masalah penelitian ini yaitu bagaimanakah kemampuan menulis paragraf deskripsi oleh siswa kelas 7 SMP Swasta Parulian 1 Medan Tahun Pembelajaran 2017-2018?

\subsection{Tujuan Penelitian}

Tujuan penelitian ini adalah:

1. Ingin mendeskripsikan kemampuan menulis paragraf deskripsi siswa kelas VII SMP Swasta Parulian 1 Medan Tahun Pembelajaran 2017-2018 sebelum menggunakan media gambar fotografi;

2. Ingin mendeskripsikan kemampuan menulis paragraf deskripsi setelah menggunakan media gambar fotografi pada siswa kelas VII SMP Swasta Parulian 1 Medan Tahun Pembelajaran 2017-2018.

\section{METODE}

Metode yang digunakan dalam penelitian ini adalah metode deskriptif kuantitatif. Sugiyono (2017) dan Martono (2012) acuan metode penelitian kuantitatif; kedua pakar metode penelitian yang melandaskan filsafat positivisme sehingga desainnya desain penelitian kuantitatif deskriptif. Pendekatan deskriptif adalah suatu metode penelitian yang ditujukan untuk menggambarkan fenomena yang ada dan berlangsung pada saat ini atau masa lampau.

Peneliti menggunakan desain ini dimaksudkan untuk menggambarkan tingkat kemampuan menulis paragraf deskripsi dengan menggunakan media gambar fotografi pada Siswa Kelas VII SMP Swasta Parulian 1 Medan Tahun pembelajaran 2017/2018. Peneliti melakukan melakukan observasi ke sekolah, kemudian menentukan jenis tes yang akan diberikan kepada siswa yang akan diteliti. Tes merupakan menulis paragraf deskriptif dan selanjutnya hasil tersebut dianalisis sebagai daya dalam menarik kesimpulan. Penelitian deskriptif digunakan mahasiswa untuk menjelaskan sesuatu hal yang diperhatikan sesuai dengan pendapat peneliti lain (Sugiyono, 2017). Penelitian ini berlokasi di SMP Swasta Parulian 1 Medan". Penentuan lokasi penelitian yaitu (1) belum pernah ada penelitian seperti ini dilaksanakan di 
sekolah

tersebut;

penulis sudah mengenal situasi sekolah tersebut sehingga akan me mberikan kemudahan dalam melaksanak an penelitian sesuai dengan keperluan; (3) Kesediaan guru bidang studi Bahasa Indonesia untuk menyusun RPP yang berkaitan dengan penggunaan media gambar dalam Standar Kompetensi Kurikulum 2013 yang bermateri. Populasinya adalah siswa kelas 7 SMP Swasta Parulian 1 Medan Tahun Pe mbelajaran 2017-2018.

Tabel 1: Populasi Siswa Kelas VII SMP
Swasta Parulian 1 Medan
\begin{tabular}{|l|l|l}
\hline NO. & KLLAS & POPULASI \\
1. & VII-1 & 40 orang \\
\hline 2. & VII-2 & 40 orang \\
\hline 3. & VII-3 & 40 orang \\
\hline & JUMLAII & 120 orang
\end{tabular}

Populasi tersebut berjumlah 120 orang siswa kelas VII SMP Swasta Parulian 1 Medan Tahun Pembelajaran 2017-2018. Dari populasi inilah di ambil wakil untuk calon yang menerima pembelajaran menulis paragraph berjumlah 33 orang siswa. Arikunto (2014) mengamanatkan penentuan sampel sebagaian atau wakil bertujuan sebagai sampel atau wakil populasi yang di teliti jika kurang dari 100 maka akan lebih baik mengambil semuanya menjadi subjek penelitian sehingga terjadilah penelitian populatif. Jika jumlah subjeknya besar, maka di ambil $10-15 \%$ atau $20-25 \%$ saja atau lebih. Dengan demikian penentuan sampelnya sebanyak $25 \%$ dari populasi, yaitu $120 \times 28 \%=32$ orang siswa.

Selanjutnya ditentukan isntrumen yang digunakan dalam penelitian ini untuk mengumpulkan data, adalah: (1) observasi langsung kepada siswa kelas VII SMP Swasta Parulian 1 Medan Tahun Pembelajaran 2017-2018. Berdasarkan pengamatannya terhadap benda yang dikenalnya yaitu buah durian maka dalam pikirannya telah tercipta pengkodean lambang bahasa dan jika dituliskannya maka ia pun mahir sebagaimana dia pernah mencatat apa-apa yang pernah dilihatnya; (2) RPP yang digunakan untuk menyususn langkahlangkah penyajian media gambar fotografi secara lengkap dengan sumber belajarnya dan dipraktikkan di dalam kelas. Di sini dikutip langkah-langkah penggunaan media dan indikator penilaiannya dalam RPP tersebut.

Langkah-langkah penggunaan media gambar fotografi:

a. Peneliti membagikan media gambar fotografi durian kepada peserta didik tiap pribadi.

b. Peneliti menjelaskan kegunaan dari gambar yang telah dibagikan tersebut.

c. Siswa diinstruksi untuk memulai menuliskan kalimat-kalimat ke dalam paragraf deskripsi dengan menggunakan media gambar fotografi durian yang dilihatnya.

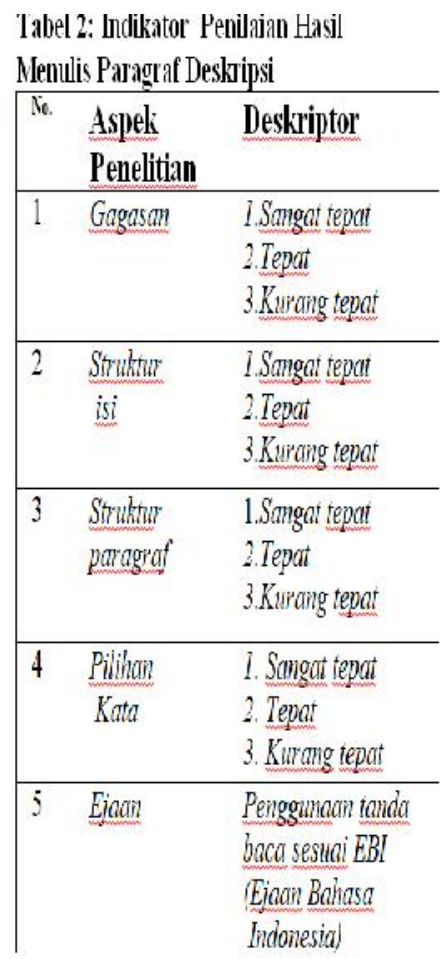

Didalam table 2 ada aspek gagasan, struktur paragraf, dan pilihan kata sangat menentukan kekohesian dan kekoherensian suatu paragraf. Untuk menilai kemampuan menulis paragraph 
deskrifsi maka peneliti menggunakan penilaian statistic deskriftif dengan cara menghitung rerata skor (M) dan simpangan bakunya atau standar deviasi (SD) dalam rumus menurut Sudjana (2001:327).
$M=$
$\mathrm{SD}=$
$\mathrm{M}=$ Rata-rata skor
$\mathrm{SD}=$ Standar Deviasi
$\mathrm{N}=$ Jumlah sampel

Selanjutnya dipresentasekan ratarata kemampuan menulis paragraph tersebut dengan menggunakan rumus sebagai berikut: Rerata Nilai=X 100.

Sebelum melaksanakan tes maka terlebih dahulu penulis memberikan sebuah kertas bergambar fotografi durian masak sebagai media untuk diperhatikan siswa kelas VII SMP Swasta Parulian 1 Medan. Tujuan mentes yaitu untuk mengetahui kemampuan siswa tersebut membuat paragraf deskripsi. Selanjutnya peneliti mengajukan satu pertanyaan saja berdasarkan gambar yang dilihatnya sendiri dalam tangannya. Siswa pun terprovokator untuk menuliskan sebuah kata-kata atau frasa dan klausa sehingga sebuah paragraf deskriptif. Para siswa mengarang minimal 3 paragraf deskripsi dalam waktu 60 menit. Hasil sebaran tes yang terkumpul dapat diolah yang diuraikan dalam hasil penelitian.

\section{HASIL DAN PEMBAHASAN}

\subsection{Hasil Penelitian}

Rincian dalam subbab judul adalah (1) prosedur penilaian kemampuan menulis paragraf, (2) pentabelan nilai kemampuan menulis paragraf deskripsi, (3) persentase kemampuan menulis paragraf deskripsi.

\section{a. Penenilaian Kemampuan Menulis Paragraf Deskripsi Masing-Masing Siswa}

Nilai tertinggi kemampuan siswa dalam menulis paragraf deskripsi ada yang bernilai tertinggi 92 dan nilai terendahnya adalah 65 . Penilaian tersebut berdasarkan indikator penilaian hasil menulis paragraf deskripsi yang terpapar sesuai indikator penilaiannya terhadap gagasannya berdasarkan media gambar fotografi yang dilihatnya maka penguasaan struktur deskripsi, pemilihan kata-kata yang tepat, kata-kata khas yang dapat menggugah pembaca; penggunaan ejaan berupa tanda baca dan huruf kapital

Tabcl 3: Skor Maksimal dan Nilai Kemampuan Menulis Paragraf Deskiripsi

\begin{tabular}{|c|c|c|c|c|c|}
\hline $\begin{array}{l}\text { Kode } \\
\text { Sampel }\end{array}$ & $\begin{array}{l}\text { Skor } \\
\text { maksinual }\end{array}$ & Nilai & $\begin{array}{l}\text { Kode } \\
\text { Sempel }\end{array}$ & $\begin{array}{l}\text { Skor } \\
\text { Iniksinnal }\end{array}$ & Nilai \\
\hline 1.P & 24 & 92 & 19-L & 27 & 92 \\
\hline $2 \mathrm{I}$ & 23 & SS & $20 \mathrm{P}$ & 23 & 83 \\
\hline 3-P & 20 & 76 & $21-\mathrm{P}$ & 22 & 84 \\
\hline H.P & 18 & $6 y$ & $22-4$ & 18 & 69 \\
\hline S.I & 24 & 92 & 23-L & 21 & 81) \\
\hline $6 \mathrm{~L}$ & 18 & 69 & $21 \mathrm{P}$ & 20 & 76 \\
\hline $7 \mathrm{P}$ & 21 & 80 & $22 \mathrm{P}$ & 23 & 83 \\
\hline 8.P & 24 & 92 & $26-\mathrm{L}$ & 24 & 92 \\
\hline 7. & 24 & $y_{2}$ & $2 \pi-4$. & $2 i$ & $\mathrm{BB}$ \\
\hline 10. I & 22 & 34 & 28-I & 24 & 92 \\
\hline 111 & 20 & 76 & $29 \mathrm{~L}$ & 23 & $8 B$ \\
\hline $12-?$ & 23 & 88 & $30-\mathrm{L}$ & 20 & 76 \\
\hline 13.7 & 17 & 65 & I1-P & 21 & RO \\
\hline 14.9 & 18 & 69 & $32-4$ & 19 & 73 \\
\hline 15.9 & 23 & 88 & 33-P & 24 & 92 \\
\hline 16:- & 22 & 84 & & & \\
\hline $17 ?$ & 19 & 73 & & & \\
\hline 1F- & 17 & 65 & & & \\
\hline
\end{tabular}

Berdasarkan nilai postesnya terangkum dalam tabel 3 di atas ini. Perhitungan total skornya untuk mengetahui Mean (M) dan standar deviasi (SD) yang hasilnya terlihat dalam tabel 4 .

Tabel 4: Frekuensi, Persentase Kategori Vilai Menulis Paragraf Deskripsi Kelas VII SMP Swasta Paiulian 1 Medan T.P. 2017-2018

\begin{tabular}{|c|c|c|c|c|}
\hline No. & SKOK & FREKUENSI & PKESEVTASE & $\begin{array}{l}\text { KATEGOKL } \\
\text { NII.AI }\end{array}$ \\
\hline 1. & $85-100$ & 14 & $42.42 \%$ & $\begin{array}{l}\text { Sangat } \\
\text { I3aik }\end{array}$ \\
\hline 2. & $74-84$ & 10 & $33,33 \%$ & Baik \\
\hline 3. & $65-73$ & 9 & $27,27^{\circ} \mathrm{u}$ & Culiup \\
\hline 4. & $55-64$ & () & $0 \%$ & Kurang \\
\hline 5. & $\begin{array}{l}45-54 \\
\pi \text { ЛА }\end{array}$ & $\begin{array}{l}0 \\
33\end{array}$ & $\begin{array}{l}0 \% \\
100 \%\end{array}$ & $\begin{array}{l}\text { Sangal } \\
\text { Kurang }\end{array}$ \\
\hline
\end{tabular}


Siswa yang memiliki kemampuan cukup berjumlah 9 orang berskala skor 65-73 sama dengan 27,27\% berkategori nilai Cukup. Siswa yang memiliki kemampuan cukup berjumlah 10 orang berskala skor 73-84 sama dengan 33,33 $\%$ berkategori nilai Baik. Siswa yang memiliki kemampuan cukup berjumlah 14 orang berskala skor 85 100 sama dengan $42 \%$ berkategori nilai Sangat Baik.

\section{b. Kategori Kemampuan Umum Menulis Paragraf Deskripsi Siswa Kelas VII SMP Swasta Parulian 1 Medan Tahun Pembelajran 2017- 2018}

Dari hasil penelitian yang telah dilaksanakan kemampuan siswa SMP Parulian 1 Medan Tahun Pembelajaran 2017-2018 dalam menulis paragraf deskripsi sudah cukup baik. Hal ini terbukti dari data yang telah diperoleh dari hasil dengan jumlah keseluruhan mencapai skor 2684 dengan nilai ratarata 81,3 (berkategori baik).

\subsubsection{Kemampuan Menulis Paragraf Bernilai Baik}

Secara keseluruhan terlihat dalam tabel 4 nilai tertinggi kemampuan menulis paragraf deskripsi. Nilai rata-rata kemampuan menulis paragraf deskripsi siswa mencapai 81,3 . Namun ditemukan keadaan siswa yang memiliki kemampuan sangat baik berjumlah 14 orang karena mereka berada dalam skala skor 85-100. Dengan kata lain bahwa siswanya berhasil ujian akhir berfrekuensi $42 \%$ dan berkategori nilai Sangat Baik.

\subsection{Pembahasan}

Keberhasilan siswa kelas 7 SMP Swasta Parulian 1 Medan Tahun Pembelajaran 2017-2018 maka peneliti menemukan paragraf deskriptif yang tertulis di lembaran jawaban ujian akhir. Siswa masing-masing menulis minimal 3 contohnya adalah tulisan minimal 3 paragraf berisi kalimat utama. Masingmasing kalimat utamanya dijelaskan lagi ke dalam lebih dari 1 kalimat. Ide atau gagasannya dalam tumpukan kalimat yang sesuai dengan isi dan struktur paragraph, ejaan melalui media visual yang tersaji dalam kegiatan pengajaran yang dilakukan guru Bahasa Indonesia didampingi peneliti. Merujuk pada saran Daryanto (2018:114) untuk menggunakan gambar yang sederhana dengan harapan siswa dapat mengungkapkannya dengan katakata sendiri berdasarkan gambar yang dilihatnya. Gambar durian masak yang diterimanya menjadi sumber belajar dan sekaligus menjadi media ajar langsung untuk berlatih menuliskan ide ataupun gagasannya dengan kata-kata sendiri. Durian adalah benda yang berupa buah yang terkenal di seluruh warga Kotamadia Medan. Tua muda mengenal buah durian. Peneliti terkesan kepada pandapat Daryanto (2018) bahwa benda yang menarik bagi setiap siswa akan menenyentuh kenangannya dengan katakata yang biasa ia dengar dan sering diucapkannya dalam berkomunikasi sehari-hari. Durian Medan sangat terkenal karena enak rasanya. Gambar durian itu dapat dideskripsikan bentuk dan warnanya ke dalam 3 paragraf deskriptif.

Upaya lain yang perlu dipahami saat menulis ke dalam unit paragraf adalah dengan penggunaan media bergambar fotografi yang bisa dijangkau seperti gambar durian yang bisa pula dihitung jumlah bijinya karena gambar duriannya terbelah. Bahkan jumlah duri kulit duriannya pun dapat dihitung dengan jarinya. Dengan demikian media gambar durian cocok untuk melatih menulis idenya ke dalam paragraf deskriptif. Dengan penggunaan media gambar fotografi ini maka peneliti merujuk pendapat Daryanto (2018:110) bahwa keuntungan yang dapat diperoleh dari gambar fotografi dalam hubungannya dengan kegiatan pengajaran yakni mudah dimanfaatkan di dalam kegiatan belajar mengajar karena praktis tanpa 
memerlukan biaya yang mahal. Kemampuan menulis paragraf deskripsi mudah dilatihkan karena setiap siswa dapat menjamah langsung gambar fotografi didasarkan atas konsep Semi (2017).. Jadi, kemampuan menulis paragraf deskripsi siswa kelas VII SMP Swasta Parulian 1 Medan telah meningkat karena media gambar fotografi terkait dengan bentuk penggambaran sesuatu hal yang diindra manusia. Siswa SMP Parulian 1 Medan tahun pembelajaran 2017-2018 telah dapat menguraikan hal yang dilihatnya dari gambar hasil kamera. Siswa SMP Swasta Parulian 1 Medan tahun pembelajaran mampu menggunakan kata-kata khas, spesifik, dan memikat untuk menggugah hati orang yang membacanya.

Kemampuan siswa SMP Swasta Parulian 1 Medan Tahun Pembelajaran 2017-2018 ini sudah baik; mereka terus berlatih menuliskan kata-kata atau kalimat yang menggambarkan keadaan durian masak yang dilihatnya itu. Emosi bersifat penglihatan, pengecapan, pendengaran, penciuman, dan perabaan siswa itu terdorong membantu kemampuan menuliskan kata-kata atau kalimat untuk menjelaskan gambar durian yang dilihatnya itu. Inilah fenomena keadaan siswa yang dilatih menuliskan kalimat ke dalam bentuk paragraf deskripsi. Dengan kemampuan ini mereka dapat diarahkan menjadi penulis deskripsi artistik. Semi (2016) mengatakan bahwa deskripsi artistik merupakan deskripsi yang memiliki nilai artistik atau nilai keindahan karena cara penyajiannya dengan menggunakan gaya bahasa sastra, biasanya dijumpai di dalam karya sastra seperti novel atau cerita pendek.

Jenis paragraf deskripsi artistik dan ekspositorik telah terimplemantasi di dalam kegiatan pembelajaran Bahasa Indonesia yang diakhiri dengan hasil postes kemampuannya menulis paragraf deskripsi. Guru pun memahami konsep paragraf deskripsi sebagai jenis paragraf yang menggambarkan suatu hal, baik benda, peristiwa, keadaan, dan manusia. Seorang penulis berusaha memindahkan kesan-kesan hasil pengamatan dan perasaannya kepada pembaca secara terperinci yang ada pada sebuah objek, sehingga pembaca melalui tulisannya, dapat melihat dan merasakan apa yang ditulis.

\section{KESIMPULAN}

Berdasarkan hasil penelitian terhadap kemampuan menulis paragraph deskrifsi dengan menggunkan media gambar fotografi pada siswa SMP Parulian 1 Medan Tahun Pembelajaran 2017-2018. Berdasarkan rumusan masalah penelitian dan hasil dan pembahasan, maka dapat di ambil kesimpulan bahwa siswa kelas 7 SMP Parulian 1 Medan Tahun Pembelajaran 2017-2018 dapat menulis paragraph deskrifsi dengan menggunkan media gambar fotografi dan rata-ratanya adalah 81,3 yang berkatagori baik.

Saranannya yang pertama perlu guru bidang studi bahasa Indonesia meningkatkan perhatiannya terhadap kemampuan menulis paragraf deskripsi siswa, dengan memberikan PBM menulis paragraf deskripsi yang lebih baik, terutama motivasi belajar kepada siswa. Sebab, dengan adanya motivasi belajar yang tinggi, siswa akan berusaha memperdalam kemampuan menulis paragraf deskripsi. Kedua, perlu peserta didik mengembangkan imajinasi serta kreativitas menulis paragraf deskripsi. Sebab, dalam paragraf deskripsi diperlukan pilihan kata-kata yang khas dan memikat yang dapat memancing emosi pembacanya; (3) hendaknya Kepala Sekolahnya agar dapat melengkapi bukubuku perpustakaan dengan banyak vairasi agar guru pun terlatih dan terampil untuk menuliskan paragraf deskriptif sehingga siswanya dapat digiatkannya latihan menulis paragraf deskriptif artistik dan ekspositorik. Guru harus mengasah dan menambah kosa kata untuk kemahiran menulis paragraf deskripsi. 


\section{DAFTAR PUSTAKA}

Arikunto, Suharsimi.

(2014). Prosedur Penelitian Suatu Pendekatan Praktek, Jakarta:

Rineka Cipta.

Daryanto.( 2018). Media Pembelajaran, Bandung: PT. Sarana Nurani Sejahtera.

Kosasih, E. (2017). Dasar-dasar Keterampilan Menulis. Bandung: CV. Yrama Widya.

Martono, Nanang. (2012). Metode Peneliti an Kuantitatif, Jakarta: PT. Raja Grafindo Persada.
Rudi, Susilana \& Riyana Cepi. (2007). Media Pembelajaran. Bandung:C

V. Wacana Prima.

Semi, Atar. (2017). Dasar-dasar Keterampilan Menulis, Bandung: Angkasa.

Sudjana, Nana. (2001). Evaluasi dalam Pengajaran. Bandung: Rineka Cipta.

Sugiyono. ( 2017). Metode Penelitian Kuantitatif dan Kualitatif.

Bandung:Alfabeta. 